\title{
KENAKALAN REMAJA DIBALIK MAKNA DAN FAKTOR PENYEBABNYA DI PANTI ASUHAN
}

\author{
Renny Dyah Kurniawati \\ Perusahaan Rokok Barito \\ kurniawatirennydyah@gmail.com
}

\begin{abstract}
Abstrak
Tujuan penelitian ini adalah untuk mengetahui kenakalan remaja yang tinggal di panti asuhan. Subjek dalam penelitian ini adalah remaja yang tinggal di panti asuhan yang memiliki karakteristik sesuai dengan pokok permasalahan, yaitu berusia 15-17 tahun yang melakukan kenakalan remaja meliputi merokok, membolos sekolah, berbohong pada pengasuh panti, keluar panti tanpa seijin pengasuh panti. Metode yang digunakan dalam penelitian ini adalah metode kualitatif dengan pendekatan fenomenologi: sebagai pengalaman subjektif, suatu studi tentang kesadaran dari perspektif pokok seseorang dengan menggunakan metode observasi dan wawancara dalam pengumpulan data. Metode analisis data menggunakan codding (Moleong, 2007). Hasil penelitian ini menunjukan bahwa kurang kasih sayang, kurang mampu mengontrol diri, mudah terpengaruh dengan teman-temannya, faktor ekonomi keluarga yang kurang, serta kurang adanya pengawasan dari orang tua, guru serta pengasuh panti membuat remaja panti berperilaku yang bertentangan dengan hukum, agama, dan norma yang berlaku dimasyarakat seperti berkelahi dengan teman, mencuri, merusak, memeras serta mencopet. Remaja juga mencoba-coba hal-hal baru yang dapat merusak dirinya sendiri seperti mencoba merokok, minuman alkohol, mencampur minuman alkohol dengan minuman soda, mencampur minuman alkohol dengan obat penghilang rasa nyeri yang dijual di pasaran atau minuman soda dengan obat penghilang rasa nyeri yang dijual di pasaran, serta minum obat penghilang rasa nyeri yang dijual dipasaran dalam jumlah banyak..
\end{abstract}

Kata kunci : Kenakalan remaja; Panti asuhan.

\begin{abstract}
The purpose of this study is to know the juvenile delinquency who live in the orphanage. Subjects in this study were adolescents who lived in orphanages that have characteristic according to the subject matter, aged 15-17 years who do juvenile delinquency include smoking, ditching school, lying on the nursing home, out of the orphanage without the permission of the nursing home. The method used in this research is qualitative method with phenomenology approach: as subjective experience, a study of consciousness from one's principal perspective by using observation and interview method in data collection. Methods of data analysis using codding (Moleong, 2007). The results of this study showed that teenagers feel less love because many children should be noticed by caregivers other than that, teenagers who are less able to control themselves, easily affected by his friends, economic factors are lacking, and lack of supervision from parents, Teachers and carers of the orphanage so that adolescents behave in opposition to the laws, religions, and norms prevailing in society such as fighting with friends, stealing, destroying, wringing and pickpockets. Teenagers also try new things that can damage themselves such as trying to smoke, drink alcohol, mix alcohol drinks with sodas, mix alcohol drinks with painkillers sold in the market or soda drinks with painkillers sold in the market, As well as taking painkillers sold in the market in large quantities.
\end{abstract}

Keywords: juvenile delinquency; Orphanage

(C) 2018 Universitas Muria Kudus 


\section{PENDAHULUAN}

Survei yang di lakukan oleh departemen sosial dan Unicef "Save The Children" pada tahun 2006 dan 2007 terhadap 37 panti asuhan di 6 provinsi di Indonesia, memberikan gambaran yang komprehensif tentang kualitas pengasuhan dalam panti asuhan di Indonesia. Bahwa kurangnya pengetahuan yang memadahi oleh pengurus panti tentang situasi anak yang seharusnya diasuh di dalam panti dan pengasuhan yang ideal diterima anak (Depsos RI, 2011).

Depsos RI (2011) juga menyatakan bahwa Panti Sosial Asuhan Anak merupakan suatu lembaga kesejahteraan sosial yang mempunyai tanggung jawab untuk memberikan pelayanan kesejahteraan sosial pada anak terlantar. Panti asuhan memberikan penyantuanan dan pengentasan anak terlantar, serta memberikan pelayanan pengganti orang tua atau wali anak dalam memenuhi kebutuhan fisik, mental dan sosial kepada anak asuh sehingga anak akan memperoleh kesempatan yang luas, tepat dan memadahi bagi pengembangan kepribadiannya.

Hasil penelitian Lusiawati (2013) berjudul "Kecerdasan Emosi dan Penyesuaian Diri Pada Remaja Yang Tinggal Di Panti Asuhan Uswatun Khasanah Samarinda". Menunjukkan bahwa di awal remaja tinggal di panti asuhan mereka merasa sedih dan perlu beradaptasi dengan lingkungan baru, teman baru atau individu yang baru pula. Seiring waktu mereka mulai membiasakan diri tinggal di panti asuhan, mampu mengendalikan perasaan ketika menghadapi masalah, namun ada beberapa remaja yang lebih memilih diam dan ketika ada masalah menyimpannya sendiri. Merasa sedih berpisah dengan keluarga namun berusaha menaati peraturan yang ada di panti asuhan.

Masalah kenakalan remaja merupakan masalah yang komplek yang terjadi di berbagai kota di Indonesia. Angka kenakalan remaja di Surabaya, Jawa Timur terus mengalami peningkatan. Di Tahun 2016, Satpol PP Kota Surabaya menangani 793 kasus dengan rincian 597 pelaku remaja laki-laki dan 196 remaja perempuan.Angka ini meningkat dibanding tahun lalu, yang hanya 675 kasus (Irvan, 2016).

Atas dasar fenomena-fenomena tersebut, maka dapat disimpulkan ada masalah kenakalan remaja di panti asuhan tersebut. Oleh karena itu penelitian tentang kenakalan remaja menjadi penting untuk diteliti.

Dalam hal inipenelitian yang dilakukan oleh Shanty, dkk (2013) yang berjudul "Faktor Penyebab Kenakalan Remaja Pada Anak Keluarga Buruh Pabrik Rokok Djarum di Kudus" menjadi pendukung penelitian dengan hasil, bahwa faktor-faktor penyebab terjadinya kenakalan remaja pada anak keluarga buruh pabrik rokok Djarum yaitu kurang tersedianya waktu orang tua untuk mendidik anak karena kesibukannya bekerja dan menyelesaikan tugas rumah tangga, tidak adanya pengawasan dari orang tua atau saudara, pengaruh lingkungan 
sekitar tempat tinggal anak, pengaruh teman sepermainan, serta karena faktor kesenangan, kepuasan, penasaran dan rasa kebanggaan dari para remaja sendiri.

Bentuk-bentuk kenakalan remaja menurut Kartono (2014) seperti kebut-kebutan di jalan, perkelahian, membolos sekolah, memeras, mencuri, mencopet, pembunuhan, mabukmabukan, agresivitas seksual, narkotika, perjudian, pertbuatan a-sosial dan anti-sosial.

Borba (2008) menjelaskan bahwa berbagai media cetak maupun media elektronik setiap hari selalu menyajikan berita tentang berbagai kasus yang melibatkan anak-anak, mulai dari pelecehan seksual, penculikan, penyiksaan, pembunuhan, perdagangan anak, anakanak yang terbelakang karena kurang gizi, anak-anak putus sekolah. Adapula kriminalitas anak yang terlibat narkoba atau menjadi pemalak, merokok, mencontek, membolos sampai dengan mencuri. Berbagai media juga muncul ancaman-ancaman seperti tayangan kekerasan, pornografi dan pornoaksi. Tindak kekerasan banyak yang dilakukan oleh para remaja dan merupakan keadaan gawat yang perlu segera diatasi.

Menurut Santrock(2007) faktor yangmempengaruhi kenakalan remaja, yaitu: identitas, kontrol diri dimana remaja tidak bisa membedakan benar salah, usia, jeniskelamin, harapan terhadap pendidikan dannilai-nilai di sekolah, proses keluarga yang kurang memperhatikan, pengaruh teman sebaya, kelas sosial ekonomi, serta lingkungan sekitar tempattinggal.

Berdasarkan uraian diatas, maka penulis tertarik untuk meneliti dan mengetahui lebih lanjut "Kenakalan remaja yang tinggal di panti asuhan".

Tujuan Penelitian

Tujuan penelitian ini adalah untuk mengetahui kenakalan remaja yang tinggal di panti asuhan serta faktor penyebab kenakalan remaja yang tinggal di panti asuhan.

Istilah kenakalan remaja atau juvenile delinquency secara etimologis berasal dari bahasa Latin. Juvenile berasal dari kata juvenilis yang berarti anak-anak atau anak muda. Sedangkan delinquency berasal dari kata delinquere yang berarti terabaikan, mengabaikan dan diperluas menjadi jahat, anti sosial, kriminal, pembuat ribut, pelanggar aturan, pengacau, penteror, tidak dapat diperbaiki, durjana, dursila, dan lain sebagainya. Juvenile delinquency atau kenakalan remaja adalah perilaku jahat atau kenakalan anak-anak muda dan merupakan gejala patologis secara sosial pada remaja yang disebabkan oleh bentuk pengabaian sosial, sehingga mengacu pada tingkah laku yang tidak dapat diterima sosial sampai pelanggaran status hingga tindak kriminal (Kartono, 2014).

Ciri-ciri Kenakalan Remaja

Jensen (1985) mengemukakan kenakalan remaja menjadi empat ciri-ciri yaitu:

a. Kenakalan yang menimbulkan korban fisik pada orang lain: berkelahi, merampok membunuh, memperkosa, dan lain-lain.

b. Kenakalan yang menimbulkan korban materi: merusak fasilitas umum, mencuri, pemerasan, mencopet, dan lain-lain. 
c. Kenakalan sosial yang tidak menimbulkan korban di pihak orang lain: penyalahgunaan obat-obat terlarang, pelacuran, dan hubungan seks bebas.

d. Kenakalan yang melawan status, sebagai pelajar dengan cara membolos, mengingkari status orang tua dengan pergi dari rumah atau membantah perintah orang tua.

Faktor Penyebab Kenakalan Remaja

Menurut Willis (2014) penyebab kenakalan remaja ada empat, yaitu :

a. Faktor Individu

Faktor yang ada di dalam diri anak sendiri yang meliputi faktor kelainan sejak kecil, lemahnya kontrol diri terhadap pengaruh negatif dari lingkungan, kurangnya kemampuan penyesuaian diri, kurangnya dasar-dasar keimanan di dalam diri remaja.

b. Faktor Lingkungan Keluarga

Faktor dari lingkungan keluarga meliputi kurangnya kasih sayang dan perhatian orang tua, lemahnya keadaan ekonomi orang tua yang menyebabkan tidak mampu mencukupi kebutuhan, kehidupan keluarga yang tidak harmonis.

c. Faktor Lingkungan Masyarakat

Faktor dari lingkungan masyarakat meliputi kurangnya pelaksaan ajaran-ajaran agama yang konsekuen, masyarakat kurang menyeluruh dalam memperoleh pendidikan sehingga berpengaruh pada orang tua dalam mendidik anaknya, masyarakat kurang mengawasi remaja, dan pengaruh norma-norma baru dari luar.

\section{d. Faktor Lingkungan Sekolah}

Faktor dari lingkungan sekolah meliputi perekonomian guru yang kurang dapat menyebabkan guru mencari kerjaan diluar sehingga anak didiknya terlantar dan kurangnya mutu guru untuk mendidik siswa, kurangnya fasilitas pendidikan yang menyebabkan penyaluran bakat dan keinginan siswa terhambat, kekompakan guru dalam menjelaskan norma-norma yang berlaku dimasyarakat.

\section{METODE PENELITIAN}

Metode penelitian yang digunakan dalam penelitian ini adalah metode peneltian kualitatif dengan pendekatan fenomenologis. Metode pengumpulan data dengan observasi dan wawancara. Informan penelitian ini adalah remaja laki-laki yang tinggal di panti asuhan yang berusia 15-17 tahun yang melakukan kenakalan remaja meliputi merokok, membolos sekolah, berbohong pada pengasuh panti, keluar panti tanpa seijin pengasuh panti. Dalam penelitian ini menggunakan metode analisis data dengan codding dan uji keabsahan data menggunakan metode trianggulasi dari salah satu pengasuh dan teman yang sama tinggal di panti asuhan dan sekelas dengan salah satu informan. 


\section{HASIL DAN PEMBAHASAN}

Berdasarkan hasil wawancara dengan ketiga informan didapatkan bahwa informan telah melakukan kenakalan remaja meskipun informan tinggal di panti asuhan.Menurut Willis (2014) kenakalan remaja merupakan tingkah laku individu yang bertentangan, perbuatan atau tindakan remaja yang asosial bahkan anti sosial yang melanggar norma-norma sosial, agama serta ketentuan hukum yang berlaku di masyarakat.

Ketiga informan merupakan remaja yang tinggal di panti asuhan karena masalah ekonomi yang kurang memadai. Informan pertama dan ketiga berusia 15 tahun serta informan kedua berusia 16 tahun. Ketiga informan mengetahui peraturan di panti namun tetap melanggarnya karena ingin bebas dan merasakan kehidupan remaja pada umumnya, bahkkan ketiga informan mencoba-coba melakukan tindakan yang melanggar hukum, agama, dan norma yang berlaku dimasyarakat, sehingga dapat merugikan orang lain, mengganggu ketentraman umum serta merusak remaja itu sendiri.

Sesuai dengan hasil penelitian Lahlah, dkk (2013) berjudul "Ethnic Differences In The Effect Of Perceived Parenting On Juvenile Violent Delinquency Of Dutch and Moroccan Dutch Boys" menunjukan bahwa lebih dari tiga perempat sampel yang diidentifikasi dari Belanda dan Morroccan Belanda yang berusia 15-18 tahun, rata-rata remaja yang melakukan kenakalan pada usia 15 tahun 8 bulan serta hampir 12\% dari sampel menunjukan bahwa dari sosial keluarga ekonomi rendah.

Menurut Jensen (1985) membedakan ciri-ciri kenakalan remaja menjadi 4 yaitu kenakalan yang menimbulkan korban fisik pada orang lain seperti perkelahian, perkosaan, perampokan, pembunuhan. Sama halnya yang dilakukan oleh ketiga informan melakukan kekerasan fisik dengan berkelahi dengan temannya karena terpancing emosi dan untuk menjaga harga diri.

Kenakalan yang menimbulkan korban materi seperti perusakan, pencurian, pencopetan, pemerasan. Ketiga informan juga merugikan orang lain dalam hal materi seperti yang dilakukan informan 1 pernah mencuri sandal, mencuri rosok panti untuk dijual, mencuri ayam, merusak tanaman warga, pemerasan pada temannya panti. Tidak jauh berbeda informan kedua juga melakukan mencuri tanaman warga, mencuri speaker dan memori, merusak tempat sampah warga karena iseng, memeras temannya panti. Informan ketiga juga melakukannya mencuri buah, helm, sepeda, ayam, sandal; merusak motor panti, merusak tanaman warga; pemerasan pada temannya panti maupun teman sekolah serta mencopet dompet dijalan.

Kenakalan sosial yang tidak menimbulkan korban di pihak orang lain seperti pelacuran, penyalahgunaan obat, dan hubungan seks bebas. Selain menimbulkan kerugian bagi orang lain ketiga informanjuga merusak dirinya sendiri informan pertama dengan merokok, minuman alkohol, mencampur minuman beralkohol dengan minuman soda minum 
obat penghilang rasa sakit dalam jumlah banyak; Informan kedua juga dengan merokok, mencampur minuman soda dengan obat penghilang rasa sakit yang dijual dipasaran; tidak jauh berbeda informan ketiga juga merokok, minum alkohol, obat yang harus dibeli di apotik dan menggunakan surat polisi, mencampur minuman alkohol, mencampur minuman alkohol atau minuman soda dengan obat penghilang rasa sakit yang dijual dipasaran, pil menyerupai narkoba yang harus dibeli dengan surat polisi, pil kletong sapi.

Serta kenakalan yang melawan status anak sebagai pelajar dengan cara membolos, mengingkari status orang tua dengan cara kabur dari rumah atau membantah perintah orang tua. Selain itu ketiga informan juga melawan status sebagai anak atau pelajar dengan membolos sekolah, keluar panti tidak ijin, melanggar peraturan panti, mencari-cari alasan atau berbohong serta membantah jika dinasehati meskipun sudah berulang kali mendapat teguran maupun sangsi.

Hasil penelitian Widianto (2008) yang berjudul "Perilaku Kenakalan Remaja Yogyakarta" menunjukan beberapa bentuk dari kenakalan remaja di Madrasah Aliyah Negeri 1 Yogyakarta meliputi bolos sekolah, merokok, mabuk-mabukan, pesta narkoba, berkelahi, mencuri, pergaulan sex bebas, pemalakan, mengakses video porno, sering terlambat masuk sekolah, seragam sekolah dan sepatu tidak rapi, kebiasaan mencorat-coret tembok, membawa dan koleksi gambar porno, rambut panjang bagi siswa.

Menurut Willis (2014) selain karena faktor ekonomi faktor yang melatarbelakangi kenakalan remaja adalah (1) faktor Individu yang meliputi bawaan sejak lahir, kontrol diri, kemampuan menyesuaikan diri, kurangnya dasar-dasar agama.

\section{Statemen informan I}

"Sama yang baru kenal? Dideketin, ngajak main, diajak ngobrol, cerita-cerita. Ikut main bersama, deket-deket sama yang lain. Beda kalau itu, kalau disekolah jarang bicara, ga pernah ketemu, jarang, cuman kan kadang diam diri kalau ga ada yang ngajak bicara, penggen sendiri, tidur. Yaa..Paling kalau ada yang bicara duluan, ewoh, kadang yaa penggen ga ewoh. Males., Deket sama yang baik, kalau dolan terus diilokke, $X$, seseorang yang sudah bareng-bareng selama 4 bulan. Berkaca kok bisa mengalami kegagalan. Ingin sukses, sukses menjadi lebih baik, bisa bantu keluarga. Yaa,, pengen bahagiain orang tua. Tergantung keadaan, kadang kan dideketi sama orang yang kurang baik."

Interpretasi informan I : menunjukkan kemampuan penyesuaian diri serta kontrol diri yang cukup baik

Statement informan II

"Ajak kenalan, jak dolan sembarang mbak ach. Yoo ojo diperaki nek lagi ngono nek ga terlalu elek tak ceraki nek kebangeten yoo ga mbak. Membahagiakan orang tua, mengangkat derajat orang tua, masuk surge mbak, penggen merubah nasip. Sekolah sinaune 
wegah dolan-dolan ngeti wong jobo nakal penggen. Aku urip koyo ga ono sing nyemangati kok mbak, yoo.. biasa-biasa ae."

Interpretasi informan II : kemampuan penyesuaian diri baik dan kurangnya kontrol diri sehingga ketika melihat orang lain anakl ia berkeinginan seperti itu

Statement informan III:

"Dingeti sifate sek jare konco sii apik-apik. Neng kula tak peraki sitek-sitek. Panti? Yaa... kenalan, kenalan dulu, semua itu butuh waktu kok mbak. Kadang orang beda-beda mbak, ujuk-ujuk tak ceraki terus malah ngko malah wonge wadulan, ujuk-ujuk apik karo aku mburine wadulan. Membawa diri. Kalau lagi mau nahan yaa nahan. Kalau baru ada beban pikiran kadang ga. penawarane menarik dingeti nyenengke konco wis marani adoh-adoh mosok ga ngajeni mbak. Penggen bahagiake wong tua."

Interpretasi informan III : kurang mampu mengontrol diri dan mudah terpengaruh oleh teman dan lingkungan

(2) faktor Keluarga yang meliputi kurangnya kasih sayang orang tua, status ekonomi, kehidupan keluarga yang tidak harmonis,

Statement informan I

"Ga terlalu jauh, kan saya disini keluarga dirumah. Kalau pas pulang diistimewain. Iku ibu sambung mbak, ga ngerti neng ndi Berterima kasih. Dulu dirumah kan ga pernah bersihbersih, sekarang kalau pulang bersih-bersih Tidak ada, enak di panti banyak teman. Pengasuh, masalahnya bantah-bantahan. Ada yang baik ada yang jelek, baiknya bisa buat santai jeleknya kadang difitnah. Berbuat baik, ga bantah."

Interpretasi informan I: hubungan dengan orang tua baik sehingga tidak kurang kasih sayang orang tua

Statement informan II

"Ibu apik aku ga tau ngomong mbi masku jarang galak oo mbak masku. Asline bapakku jeh ono mbak tapi ga dianggep wong wis ninggalke aku jeh neng kandungan. Yoo apik ga tau ngaru-aru, nek ibu iku yoo ngomong terus, Semenjak iku teko atiku koyo piye kok mbak, koyo tertekan. Neng omah nakal mbak, neng kene maleh ogak, maksude dek iko aku karo ibu nakal ga paham sakiki nek muleh wis ga. Yoo gah, tapi piye neh aku metu meh dadi opo mbak ga ono sing nyekolahke aku. Yoo mikir ngono, neng atiku yoo pengen metu neng cita-citaku piye mosok aku koyo wong dalan-dalan. Penggen metu yoo kerjo ngono iku boto, bangun. Yoo menjauh, nek diseneni yoo jaluk maaf biasane tak barno, lali-lali dewe"

Interpretasi informan II: hubungan dengan ibu baik meskipun tidak tau ayahnya sehingga informan kurang mendapatkan kasih sayang seutuhnya dari figur ayah dan kakak yang galak membuat keluarga yang dirasa kurang harmonis

Statemen informan III 
"Baik saja. Tapi kelas 8 saking nakale kulo, nganti bapak tegel ape mukul, Sangking nakale neng kene digunduli, Pas kulo discores bapak neng Bali. pinggen bahagiake wong tua, Tergantung pergaulane., nek lagi nakal sekali metu yaa sisan sing adoh. Nek pak $P$ apik, mas $S$ yaa apik mergane wis tau ngrasakno neng kene. Jane iso dikandani mbak tapi nek lagi nakal-nakale luweh langsung nakal sisan podo-podo diseneni. Aku sebenere nyaman mbak, angger oleh muleh kan mesti duwe rasa kangen mbi wong tua. Nek bu R mesti ditakon-takoni ngapa muleh nek dijawabi kangen wong tua, dijawab nek kangen wong tua kabeh do muleh panti sepi dipal ngono mbak. Neng omah jarang sholat neng kene sholat, nengomah jarang ngaji neng kene ngaji terus, neng omah yoo ga tau resek-resek jarang ngepel neng kene resek -resek terus nyapu ngepel diajari kabeh. Pas nakal-nakale yoo kudu keluar neng sek mikir mburine barang nek mandek sekolah masa depanku piye."

Interpretasi informan III: hubungan keluarga baik meskipun kurang harmonis.

(3) faktor lingkungan masyarakat yang meliputi kurangnya pelaksaan ajaran-ajaran agama yang konsekuen, masyarakat kurang menyeluruh dalam memperoleh pendidikan, masyarakat kurang mengawasi remaja, dan pengaruh norma-norma baru dari luar,

Statement informan I

"Nek ketemu nglorohi nek tau roh nglorohi. Khajatan, disini pengajian kadang ada acara tetangga anak panti diundang, ikut sholat jenazah disini. Kalau disini banyak kaya ngrokok, judi, main poker, main wanita ada banyak wanita laki-lakine sitik. Paling do ga roh, sing ngerti paling cah nom-nom sing do bal-balan. Ketutupan tebu terus ono enggon cetakan boto. Aku biasa ae tak cueki aa mbak nek tak iloke ngko ngamuk marai perkoro,"

Interpretasi informan I: lingkungan yang negatif sehingga sedikit terpengaruh normanorma dari luar dan selain itu kepeduliannya dengan lingkungan

Statement informan II

"Aku kan kos sii mbak dadi ga due tonggo. Yoo nek ono sing gelem ngomong yoo ngomong, kose pindah-pindah, yoo ngetoke apike. Ga ono paling neng panti 17an lombalomba neng panti. Omongan tok mbak ga ngantek piye-piye, neng kos ga ono mbak kan ono peraturane, kadang ono sing gremeng doo metu liwat buri kon, paling nek silaturahmi yoo apik. Nek ngono iku ga tau nek ga neng kene tau ngerti."

Interpretasi informan II: kurangnya peduli dengan lingkungan

Statement informan III

"Cedak mbak wong mepet-mepet omah kiwa tengen ngarep yaa latare cedak. Ndek anyar-anyare neng kene ditakon-takoni "gek anyaran neng kene? ke nek neng kono lah angger ga koyo neng kono modele ngeti dewe nek meninggal angger dipendem ogak ono dingajike tah pye" nekaku wis reti mbak angger tak jawab nggih. berjanjen kadang yaa diken khajatan, Dipanti? Ga pernah. Yaa ada yang baik ada yang jelek. Yaa tetangga rada jauh sukae minum-minuman keras,judi ga nutuke sekolahe. Aku yaa ditawani ibu ngoten nek 
pancen wis ga kuat neng kono, ancen aku ga iso nyekolahke neng omah melu kerja bapak neng Bandung. Podo-podo ninggalke omah mending luru ilmu. Kadang yaa dirasani. Kadang aku dikandani ibu,ke ga usah dolan karo wong iku, nangging aku ijeh dolan mbi cah iku nek didepan wong tua kan elik kelakuane tapi aku jeh dolani. Apa sing didelok kan urung mesti mbak. Kalau disini ga tau, paling jagong nek liwat yaa angger liwat. Yaa angger tak ajeni mbak, nek wonge ngajeni aku yaa ngajeni."

Interpretasi informan III: kurangnya ajaran agama yang konsenkuensi, masayarakat yang kurang menyeluruh dalam memperoleh pendidikan dan pengaruh norma baru dari luar

(4) faktor dari lingkungan sekolah meliputi perekonomian guru yang kurang dapat menyebabkan guru mencari kerjaan diluar sehingga anak didiknya terlantar dan kurangnya mutu guru untuk mendidik siswa, kurangnya fasilitas pendidikan yang menyebabkan penyaluran bakat dan keinginan siswa terhambat, kekompakan guru dalam menjelaskan norma-norma yang berlaku dimasyarakat.

Statement informan I

"Yaa ada yang baik ada yang jelek ahh, baiknya perhatian sama anak didiknya, kan ada yang pilih-pilih ada yang baik sama semuanya. pamane cah pondok diduworno diurusi cah pondoke cah panti ga, koyo pelajaran tah kegiatan apa sing diajuke cah pondok. dibiayai orang lain. Kalau ada mainan terus males, pas ada cod mbak. Baik sii gelem nglorohi tapi aku kadang ga mau kumpul, yaa kadang tak tinggal tidur rasane males jagong. Yaa kurang nyaman, kalau hujan kehujanan belakang kan belum ada jendelanya. Yaa kadang gurune teko-teko wis cemberut ngamuk-ngamuk, Yaa harus ningkatke kepinterane, perilakune iso diubah perilaku kan elek diubah apik. Kan tergantung gurune nek ijeh ga mrehatikno yoo wis."

Interpretasi informan I: fasilitas sekolah yang kurang memadahi serta ada sebagian dari gurunya yang membedakannya dari murid lainnya

Statement informan II

"Ono sing pilih kasih mbak. Ga tak rungoke pelajarane, kaet angkatane mas S mbak pengasuh kene, harene gurune ncen ngono kwi. Yoo pengen ngerubah nasip orang tua, pengen sukses. Yoo pelajarane mbak mangkat gendadapan mulehe setengah 2 bosen ngono terus, bar subuh turu aduse kesuen yoo iku mau konco, gurune yoo podo ae ngono. Apik tapi rak tau ngomong ewoh ngono oo mbak mbi cah panti rak tau omong konone ewoh aku yoo podo ae ono sing bedakno aa mbak cah pondok kwi. Yoo beda kadang ngomak - ngamuk dewe, konco ga dianggep konco. Nek neng dalan yoo tak lorohi kadang konone nglorohi. Nek sekolah tok ngono. Lumayan, enak internet urung ono kantine urung ono. Gowo menengmeneng nyatane angger do gowo HP."

Interpretasi informan II: kurangnya fasilitas sekolahan serta guru dan teman-temannya selalu membedakannya dengan yang lainnya

Statement informan III 
"Kadang ono sing getengke mbak, pereh urip neng panti direndahno kadang yoo nyeneni, lya pas nglakoke kesalahan nangging kan nek nyeneni ga usah dogowo-gowo jenengan panti,pereh aku urip neng panti kok direndahke. Yaa serik aa mbak, ameh tak padoni yaa pye wong sekolah neng kene. wis dikhianati mbak. Angger wonge khianati tak gawe seneng ben go semangat sekolah mbak. Kadang yaa temen-temen putri. Pelajarane, gurune. Gurune nek nyeneni ngoten tak seriki mbak, kadang yaa tak tinggal turu nek pelajarane ga enak malah gurune sing ga ngajar difoto disebar-sebarke didudohke sing adol kantin. Baik mbak, kulo ulangan ga bisa aku langsung tanya sama temen putri yang baik sama saya yaa ditiruni. Ga ada mbak, sekolah yaa angger ngonten angger wayah sekolah yaa sekolah, muleh yaa muleh. Fasilitase ga lengkap kok mbak, ga ada komputere, fasilitase yaakurang kok mbak."

Interpretasi informan III: pembedaan dirinya dengan murid lainnya serta fasilitas yang kurang

Dari ketiga informan, informan pertama mengetahui cara menyesuaikan diri namun ketika dengan teman sekolah lebih memilih menyendiri karena merasa tidak enak atau malas, kurang kontrol diri sehingga menyebabkan mudah terpengaruh oleh temannya, mudah terpancing emosi, informan kedua mengetahui cara mengontrol diri namun terkadang mudah terpengaruh orang lain, Mengetahui cara menyesuaikan diri namun tidak dekat dengan teman sekolah, malas dengan rutinitas sehari-hari sekolah terus, mudah tersinggung dan terpancing emosi; informan ketiga remaja yang kurang mampu mengontrol diri mudah terpengaruh dengan keadaan. Dari faktor keluarga ketiga informan merasa kurang mendapatkan kasih sayang serta dari keluarga yang ekonominya kurang, sikap pengasuh yang kurang memperhatikan dan menjadi penganti orang tua pada anak panti. Ketiga informan juga kurang mampu untuk memilih teman serta membedakan benar salah. Ketiga informan ketika disekolah dibedakan oleh gurunya sehingga informan merasa tidak nyaman disekolah dan melampiaskan diluar sekolah.

Hasil penelitian Lucero, dkk (2015) yang berjudul "An Examination Of Family and School Factors Related To Early Delinquency" menunjukan bahwa kenakalan dipengaruhi oleh faktor individu yang meliputi rasa ingin tahu, etnis, status dan jenis kelamin. Faktor ekonomi keluarga yang kurang serta orang tua yang tidak lengkap dalam mengasuh berpengaruh pula pada kenakalan remaja ditambah dengan pendidikan karakter di sekolah yang kurang memberikan pengarahan.

Pada informan pertama pernah mengalami kekerasan oleh salah satu pengasuh karena pergi bermain serta informan kedua yang merasa tertekan dengan adanya salah satu pengasuh. Sesuai dengan hasil penelitian Asseggaf (2014) dengan judul "Pola Pengasuhan Anak Terlantar Di Panti Sosial Asuhan Putra 4 Ceger Cipayu Jakarta Timur" menunjukan bahwa pengasuh yang menggunakan pola asuh demokratis dengan tujuan melatih anak 
menjadi percaya diri dan bertanggung jawab sehingga anak dapat mandiri dan menentukan pilihannya namun jika melakukan kesalahan akan menerima resiko dari perilaknya agar lebih dewasa dan matang berfikir namun kenyataannya banyak anak panti yang menyalahgunakan kebebasan dan menimbulkan masalah. Pengasuh yang menggunakan pola asuh otoriter banyak anak yang merasa tidak nyaman serta seringkali kabur jika mendengar suara pengasuh.

Informan pertama dan kedua merasa berbeda dengan teman sekolah karena tinggal di panti asuhan serta informan kedua merasa takut jika orang tuanya mengetahui perbuatannya. Temuan penelitian Farooqi (2009) dengan judul "Differences In Self-Esteem Of Orphan Children And Children Living With Their Parents"menunjukan bahwa anak yang tinggal di panti asuhan memilik harga diri yang rendah dibandingkan yang tinggal dengan kedua orang tuanya dalam memahami keadaan emosional dan perkembangan kepribadian.

\section{KESIMPULAN}

Berdasarkan hasil penelitian pada ketiga informan, dapat di simpulan bahwa informan melakukan kenakalan remaja seperti melakukan kekerasan pada orang lain bahkan pada temannya sendiri karena emosi dan menjaga harga diri agar tidak dikucilkan. Ketiga informan juga merugikan orang lain dalam hal materi seperti mencuri, merusak, memeras serta mencopet.

Selain itu ketiga informan mencoba-coba hal baru. Informan pertama mulai mencobacoba merokok, minum alkohol, mencampur minuman beralkohol dengan minuman soda, minum obat penghilang rasa sakit yang ditemukan dipasaran dalam jumlah banyak. Kemudian ketiga informan tersebut juga membolos sekolah, keluar saat jam pelajaran, keluar panti tidak ijin, melanggar peraturan panti, mencari-cari alasan atau berbohong, serta membantah jika dinasehati.

Kemudian juga dapat di ambil kesimpulan bahwa Faktor yang melatarbelakangi perilaku tersebut karena kurangnya kemampuan mengontrol diri, mudah terpengaruh dengan temannya, kurang mendapat kasih sayang, faktor ekonomi keluarga yang rendah, serta kurangnya pengawasan dan kontrol dari pihak panti maupun sekolah.

Saran

a. Bagi remaja yang tinggal di panti asuhan memiliki tugas dan tanggung jawab yang sama dalam mengendalikan diri atau perbuatan sesuai aturan. Sehingga dalam hal ini, remaja perlu menyusun kegiatan produktif melalui pertemuan rutin atau diskusi dalam membahas strategi pengendalian diri dan mematuhi aturan di panti asuhan.

b. Bagi pengasuh panti asuhan, setiap pengasuh memberikan kesempatan yang sama tanpa membandingkan tingkah laku di antara remaja. Oleh karena itu, para pengasuh memberikan tempat dan waktu cukup untuk dapat melakukan sharing atas tingkah laku baik dan buruk serta cara mengatasinya bersama. 
c. Bagi peneliti selanjutnya, terus mengkaji lebih dalam fenomena kenakalan remaja yang tinggal di panti asuhan sehingga dapat memberikan sumbangan teoritis tentang kenakalan remaja pada psikologi sosial

\section{DAFTAR PUSTAKA}

Asseggaf S.L. (2014). Pola Pengasuhan Anak Terlantar Di Panti Sosial Asuhan Putra 4 Ceger Cipayu Jakarta Timur. Skripsi (Diterbitkan): Program Studi Kesejahteraan Sosial Fakultas Dakwah Dan IImu Komunikasi Universitas Islam Negeri Syarif Hidayatullah Jakarta.

Borba M. (2008). Membangun Kecerdasan Moral "Tujuh Kebijakan Utama Agar Anak Bermoral Tinggi"Gramedia Pustaka Utama Jakarta.

Departemen Sosial Republik Indonesia. (2011).Standar Pelayanan Pengasuhan.Jakarta : Mentri Sosial Republik Indonesia

Farooqi, dkk. (2009). Differences In Self-Esteem Of Orphan Children And Children Living With

Their Parents.Department of Applied Psychology, University of the Punjab, Lahore, Pakistan, Vol 46 No 2.

Irvan. (2016). https://www.merdeka.com/peristiwa/kenakalan-remaja-meningkat-rumahhantu-jadi-tempat-kongkow.html diakses pada 15 Desember 201621.44

Jensen, L.C. (1985). Adolescence: Theories, Research, Applications. St. Paul, San Fransisco: West Publising Co.

Kartono. (2014). Patologi Sosial 2 Kenakalan Remaja. Jakarta : Raja Grafindo Persada.

Lahlah, dkk. (2014). Ethnic Differences in the Effect of Perceived Parenting on Juvenile Violent

Delinquency of Dutch and Moroccan-Dutch Boys. International Victimology Institute Tilburg, Vol 23.

Lucero dkk. (2015). An Examination Of Family and School Factors Related To Early Delinquency. National Association Of Social Workes, Vol 37, No 3.

Lusiawati. (2013). Kecerdasan Emosi Dan Penyesuaian Diri Pada Remaja Yang Tinggal Di

Panti Asuhan Uswatun Hasanah Samarinda.JurnaL: Psikologi fisip unmulSamarinda. Moleong. (2007). Metodelogi Penelitian Kualitatif Edisi Revisi.Bandung : Remaja Rosdakarya. Santrock. (2007). Remaja Edisi 11 Jilid 2. Jakarta : Erlangga.

Shanty dkk. (2013). Faktor Penyebab Kenakalan Remaja Pada Anak Keluarga Buruh Pabrik Rokok Djarum Kudus. Skripsi(Diterbitkan): Jurusan Politik dan Kewarganegaran Fakultas IImu Sosial Universitas Negeri Semarang

Widianto, A. (2008). Perilaku Kenakalan Remaja Yogyakarta. Skripsi (Diterbitkan) : ProgramStudi Sosiologi Agama Fakultas Ushuluddin UIN Sunan Kaalijaga Yogyakarta.

Willis S. (2014). Remaja \& Masalahnya. Bandung : Alfab. 